\title{
Individual's level of education as a guarantee of the right to defense
}

\author{
Oleksandr Shevchyk* and Andrii Hnatiuk \\ Poltava Law Institute of Yaroslav Mudryi National Law University, Poltava, Ukraine
}

\begin{abstract}
The right to defense is enshrined in national legislation, including Art. 59 of the Constitution of Ukraine, according to which, "Everyone has the right to a professional legal assistance. In cases provided for by law, this assistance is free of charge" [1]. In addition, there is Art. 52 of the Criminal Procedural Code (CPC) of Ukraine [2]. The lack of an appropriate level of education cannot be regarded as a certain mental defect or the fact of not speaking the language, since individuals could have an appropriate oral skill in Ukrainian, but not written skills. The problem lies not only in the lack of a unified approach in the practice of law enforcement regarding the application of legal grounds for the mandatory provision of a lawyer in criminal proceedings for persons who do not have the appropriate level of education, but also in the lack of a strictly defined level of education that would be considered sufficient to ensure persons' right to protection.
\end{abstract}

Key words: level of person's education, right to defense, obligatory participation of a lawyer in criminal process.

\section{Introduction}

The relevant principle of the right to defense is enshrined in national legislation, including Art. 59 of the Constitution of Ukraine, according to which, "Everyone has the right to a professional legal assistance. In cases provided for by law, this assistance is provided free of charge" [1]. In addition, there is Art. 52 of the Criminal Procedural Code (CPC) of Ukraine [2]. This study is based on Ukrainian regulation acts, scientific researches using dialectical, comparative, analytic, synthetic and comprehensive methods.

\section{Aim}

The aim of this research is firstly - to investigate interrelation between the defendants' level of education and ensuring of their right of defense, and secondly - to propose legal adjustments in this sphere.

\section{Material and methods}

This study examines provisions of international documents and scientists' attitudes. Authors analyze generalized information from law database of different countries by means of scientific methods from a legal point of view. This article is based on dialectical, comparative, analytic, synthetic and comprehensive research methods.

\footnotetext{
* Corresponding author: a.s.shevchik@ukr.net
}

(C) The Authors, published by EDP Sciences. This is an Open Access article distributed under the terms of the Creative Commons Attribution License 4.0 (http://creativecommons.org/licenses/by/4.0/). 
In order to achieve this goal International Covenant on Civil and Political Rights (ICCPR), Constitution of Ukraine, Law enforcement acts and legislation of other states along with practice of ECtHR have been analyzed. The international experience of Russian Federation, Kazakhstan, Uzbekistan, Belarus, Poland and other countries are investigated. During the study, methods of data extraction and content analysis were used.

The methodology of this scientific publication is based on the organic combination of philosophical approaches, general scientific and special legal research methods. In particular, the systematic method is used to carry out a systematic analysis of legislative acts of other countries. The comparative method allows the author to compare the experience of foreign countries in terms of ensuring the right to defence for persons with inappropriate level of education. The legal modelling method is used to formulate proposals in order to improve existing legislation and practice.

The analysis of scientific sources clearly shows that described in this article problems have not been studied sufficiently.

\section{Results and discussions}

One of the generally acknowledged rights at the international level is the right to defence from suspicion and prosecution of a crime. The International Covenant on Civil and Political Rights, ratified by Decree of the Presidium of the Supreme Soviet of the Ukrainian SSR on 19.10 .73 , in article 14, paragraph 3 (d), stipulates that everyone has the right to be tried in his presence, and to defend himself in person or through legal assistance of his own choosing; to be informed, if he does not have legal assistance, of this right; and to have legal assistance assigned to him, in any case where the interests of justice so require, and without payment by him in any such case if he does not have sufficient means to pay for it [3].

Provision of the accused with the right to defence under art. 129 of the Constitution of Ukraine is the basic principle of legal proceedings [1], and according to Art. 7 of the Criminal Procedure Code of Ukraine [2], ensuring the right to defence is one of the general principles of criminal proceedings.

The right to defence is enshrined in Art. 59 of the Constitution of Ukraine [1], according to which, "everyone has the right to professional legal assistance. In cases provided for by law, this assistance is granted free of charge."

This norm is reflected in other national legal acts, according to which the person is provided with the right to use the legal assistance of a lawyer, both on the basis of contractual relations and free of charge, with the involvement of advocate from the Centre of free legal aid. Such guarantee meets the requirements of international law. At the same time, it should be noted that the list of cases of compulsory appointment of a defender to the accused person is not sufficient and need some law adjustment on the basis of the following.

Thus, in the Criminal Procedure Code of Ukraine (Article 52) it is determined that a lawyer is necessarily appointed to a person by an investigator, prosecutor, judge-investigator or a court in a criminal proceeding concerning grievous crimes from the moment a person acquires the status of a suspect [2].

The following article expands the list of cases for mandatory involvement of a lawyer for defence of the following categories of persons: to persons who are suspected or accused of committing a criminal offense under the age of 18 years - from the moment of establishment the fact of a juvenile or the emergence of any doubt that the person is an adult; with regard to persons for whom enforcement of the compulsory measures of an educational nature is foreseen, - from the moment of the establishment of the fact of a minor or any doubt as to the fact that the person is of an adult age; with respect to persons who, due to mental or 
physical defects (dumb, deaf, blind, etc.) are not able to fully realize their rights, from the time these defects are established; with regard to persons who do not speak the language of criminal proceedings - from the moment of establishing this fact; with regard to persons for whom the use of compulsory measures of a medical nature is foreseen or the question of their application is being decided - from the moment of the establishment of the fact of mental illness or other doubts of its sanity; on the rehabilitation of the deceased person - from the moment of the right to rehabilitation of the deceased person; with regard to persons in respect of which a special pre-trial investigation or a special legal proceeding is carried out - from the moment of the adoption of the corresponding procedural decision; in case of conclusion of an agreement between the prosecutor and the suspect/accused with confession of guilt from the moment of initiating the conclusion of such agreement [2].

In most cases, similar norms are contained in the legislation of the countries that belonged to the Union of Soviet Socialist Republics. At the same time, both in the Criminal Procedure Code of Ukraine and in the legislation of a number of other countries, cases of compulsory involvement of a lawyer as a defender of a person subject to criminal prosecution are exceptional. That is, the legislator does not provide for the possibility of an expanded interpretation of the relevant cases. In particular, the analysis of criminal procedural legislation of countries such as the Russian Federation, the Republic of Belarus, the Republic of Latvia, the Republic of Kazakhstan and the Republic of Uzbekistan also indicates that cases of compulsory involvement of a lawyer are exhaustive [4-8].

At the same time, it is considered that not all categories of persons to whom the mandatory involvement of a lawyer is provided, have the opportunity to properly exercise their right to protection. Art. 20 of the CPC of Ukraine, which reveals the content of the right to defence as a general basis for criminal proceedings, secured the right of a suspect, accused, acquitted, convicted to defence, which guarantees him with the opportunity to provide oral or written explanations on suspicion or accusation; to exercise other procedural rights provided for by the CPC [2].

The realization of procedural rights consists, among other things, in drafting by a prosecuted person of procedural documents (applications, complaints, petitions, etc.), which in turn determines the need of appropriate level of writing, the ability to read with understanding, the ability to reasonably justify the position. A person acquires the appropriate skills by education. In this case, education is associated with the formation of the key competencies necessary for each person to live. Common competences for all are the following skills: reading with understanding, ability to express their own opinion orally and in writing, critical and systematic thinking, ability to logically justify a position, etc. In turn, competence is a dynamic combination of knowledge, skills, thinking patterns, which varies depending on the level of education received [9].

It is rather clear that a person who due to certain living conditions did not acquire an adequate level of education or did not get any education at all, despite the attainment of adulthood or the absence of mental defects, is not able to properly defend himself against criminal prosecution due to the lack of appropriate skills.

The analysis of law enforcement practice shows that in case of criminal prosecution of a person, her personal data regarding education and its level are established. We believe that establishing the fact of persons' education and its level is an important fact for further ensuring proper legal procedures in criminal prosecution and further ensuring the right to defence.

The Constitution of Ukraine states that full secondary education is compulsory [1]. This provision is also enshrined in the Law of Ukraine "On Education" (Part 2, Article 12), which states that full comprehensive secondary education in Ukraine is mandatory and acquired in 
institutional or individual forms defined by law, mostly in educational establishments [9]. That is, the legislator has determined that a person who is living in Ukraine must have certain knowledge and competencies to be productive person in society.

It is also worth noting that the constitutional obligation to obtain a certain level of education among the countries mentioned above is enshrined not only in Ukraine, but also in the Republic of Kazakhstan, the Russian Federation, Latvia, and many other European countries, such as Poland, where at Constitution and legislative level it is compulsory to undergo training for up to 18 years [10-13]. For example, Poland has 5 levels of education that include: pre-school, primary, secondary or high school, high school and higher education. In Kazakhstan and Uzbekistan there are 7 levels of education, 11 levels of education in the Russian Federation, 6 levels of education in the Republic of Belarus, and 4 levels of education (preschool, basic (compulsory), secondary education and higher education) in Latvia.

Let us consider the purpose of education as such and why its availability, in our opinion, is a mandatory element which influences the possibility of individual to defend himself personally.

The goal of education is the comprehensive development of a person being the highest value of society, encouraging of its talents, intellectual, creative and physical abilities, formation of values and necessary for the successful self-realization of competencies, education of responsible citizens who are capable of conscious social choice and directing their activities in favour of other people, society, the enrichment on this basis of intellectual, economic, creative, cultural potential, etc. [9]. Consequently, based on the above definition, one can conclude that the education of a person is a priority of society in general, since the uneducated society is not able to realize its potential, and the development of the state in the European direction, chosen by our country, depends on an increase the number of lawconscious citizens.

The goal of comprehensive secondary education, which is mandatory in Ukraine, is the comprehensive development, upbringing and socialization of the individual capable of living in a society and civilized interaction with nature, has a desire for self-improvement and lifelong learning, is ready for a conscious life choice and self-realization, responsibility, work and civic activity. Achievement of this goal is ensured by forming the key competencies necessary for every person to succeed in life, including proficiency in national language and the ability to communicate with their native (in case of difference with the state language) and foreign languages [9].

The lack of the proper level of education can certainly indicate the lack of proper language proficiency. Judiciary in Ukraine, as well as in most countries of the world, is provided for in the state language. Accordingly, drafting of procedural documents, conducting investigatory and procedural actions take place in the state language. Language proficiency is acquired in the course of studying. Thus, according to the European Language Education Recommendations, there are six levels of language proficiency developed by the Association of Language Experts in Europe: Introductive (Breakthrough or A1), average (Waystage or A2), the Threshold, or B1), advanced (Vantage or B2), autonomous (Effective Operational Proficiency or C1) and competent (Mastery or C2). They cover the gap between the basic and fluent level of language proficiency.

A significant problem is that current legislation does not establish criteria for determining the "sufficient level of state language proficiency" needed to provide a person with the ability to protect their rights independently. There is also no single approach to the definition of a competent entity that would implement an appropriate "sufficient level of state language proficiency". 
At the same time, in cases when the person against whom the prosecution is conducted does not understand the state language or the language in which the proceedings are conducted, the person concerned is guaranteed (to ensuring the right to defence) the right to an interpreter and right to have a lawyer (paragraph 18 Part 3 of Article 42 and Item 4 of Part 2 of Article 52 of the CPC of Ukraine) [2].

But the language proficiency also includes the proper level of abilities for oral and written communication.

In some cases, if there is any doubt as to the level of language proficiency, there is the possibility of appointing a linguistic expertise. Linguistic expertise is a specialized linguistic study of text materials and other linguistic objects in order to clarify issues that may have legal implications. Objects of research are texts of oral and written speech, verbal, alphanumeric, phonetic and combined signs, as well as gestures and facial expressions. However, the cases of appointment of such expertise in order to establish a sufficient level of language proficiency as the guarantee of the right to defence against criminal prosecution are essentially isolated cases. Conducting of linguistic expertise causes additional time and financial costs. Moreover, the lack of an approved methodology for conducting relevant examinations and unified approach to the minimal allowable level of language proficiency, for the person to defend him-/herself personally, is clearly a huge problem.

At the same time, individuals may even have a high level of ability to use information from various oral sources, but the relevant skills may not always ensure individual to have the appropriate level of ability to use information from written sources. A person may have no written skills at all, but may have moderate oral skills. Such cases are not uncommon among persons of Roma and other nationalities [14].

The lack of a proper level of ability to extract information from written sources is an obstacle to the realization of the right to defence, since the person concerned is deprived of the opportunity to familiarize himself with the content of the criminal procedural materials (procedural documents and written evidence).

The lack of the proper level of language proficiency also deprives an individual of drafting of procedural documents, applications, petitions, complaints, etc., which also indicates that a person is not able to use the right to defence independently.

Moreover, lack of possibility to use information from written sources and, consequently, the lack of written skills cannot be offset by the participation of the interpreter.

The ability to extract information from various oral or written sources, the ability to generalize it and make a justified statement in a coherent form is acquired while achieving education. And the fact of acquiring a corresponding level of education by a person is an adequate confirmation of language proficiency level.

In some cases, deciding on the involvement of a lawyer, according to Art. $52 \mathrm{CPC}$ of Ukraine, Ukrainian national courts as the legal basis for the mandatory participation of a lawyer in criminal proceedings refer to the provisions of paragraph 4 of Part 2 of Art. 52 CPC of Ukraine, that is provide such guarantee for persons who do not speak the language of criminal proceedings. In other cases, the courts facing the fact of the absence of persons' appropriate level of education as the legal basis for the involvement of a lawyer in a criminal proceeding refer to the provisions of paragraph 3 of Part 2 of Art. 52 CPC of Ukraine, that is regulate an obligatory participation of a defense counsel in criminal proceedings for persons with mental defects [2].

The lack of an appropriate level of education cannot be regarded as a certain mental defect or the fact of not speaking the language, since individuals could have an appropriate oral skill in Ukrainian, but not written skills. In most cases of criminal proceedings, courts first establish the fact that there was no adequate level of education of the person prosecuted and decide to engage a lawyer in accordance with art. 52 CPC of Ukraine as a compulsory 
participant in criminal proceedings. Therefore, the fact of the revealed violation of the right to defence during the pre-trial investigation leads to the recognition of evidence gathered during the pre-trial investigation as inadmissible. Moreover, it leads to the court decision to close criminal proceedings on the basis of clause 3, part 1, Article. 284 of the CPC of Ukraine as for failure to establish sufficient evidence to prove the guilt of a person in court and to exhaust the possibilities of obtaining it [2].

We note that an important part of the right to defence in criminal proceedings is also to ensure the effectiveness of defence at all stages of criminal proceedings.

Thus, at the initial stages of the criminal prosecution of a person (the presentation of a suspicion) there must be an obligation of the state to provide effective defence to the person. At the same time, the prosecution authorities are already endowed with sufficient capabilities to promptly determine persons' level of education. Thus, even at the stage of the pre-trial investigation, in particular during certain investigative actions (interrogation), an investigator, prosecutor or another person who is empowered to conduct an interrogation is required to evaluate the level of education of prosecuted person. The corresponding obligation is conditioned, in particular, by the presence of a mandatory graph in the relevant interrogation protocol. However, determining of person's education and its level in most cases is purely formal. Also, there is no clear criterion for criminal prosecution authorities to determine minimal allowable level of education of a person to ensure its right to defence. Thus, the possibility of securing a person's right to defence is lost from the very beginning of criminal proceedings.

Determining the level of language proficiency or the presence of mental defects that could be an obstacle to the person's right to defend himself independently requires special knowledge and an expert study, and therefore - time, which could affect reasonable time frame of criminal proceedings. Determining of persons' education and its level does not require significant efforts or time expenditures for law enforcement officials. Instead, it can be a guarantee of the observance of the person's right to defence at all stages of the criminal proceedings.

Cases where a lawyer had not been appointed for the defendant or accused during a pre-trial investigation (when he must be compulsorily involved), cast serious doubt on the question of the affiliation and admissibility of the evidence on which the prosecutor's accusation was based.

The legal position of the ECtHR regarding the initial stage of securing the right to defence in criminal proceedings is set forth, in particular, in paragraph 63 of the ECtHR judgment of June 9, 2011 in the case of Lucianinov v. Ukraine, which states that for accused to exercise his right to defence he must be guaranteed with the opportunity to get effective help of the advocate from the very beginning of the proceedings (paragraph 52 of the ECtHR judgment of 27 November 2008 in the case of Salduz v. Turkey and paragraphs 90 to 91 of the ECtHR judgment of 12 June 2008 in the case of Yaremenko v. Ukraine).If necessary, the defender must be appointed officially. The fact of appointment defence counsel by the national authorities does not guarantee effective legal assistance in itself (paragraph 65 of the ECtHR judgment of 19 December 1989 in the case of Kamazinski v. Austria).

Appointment of a counsel in a court proceeding in cases where a defendant, accused during a pre-trial investigation had not been appointed, a defence counsel cannot in itself restore already violated right to defence.

At the same time, the lack of an adequate level of education, as noted earlier, is an obstacle to the realization of a full-fledged right to defence personally. We believe that in case of absence of an adequate level of education the person against whom prosecution is being pursued must be provided with the defence counsel on compulsory basis. 
As was already mentioned, in the Criminal Procedure Code of Ukraine (as in a number of other countries) cases of mandatory involvement of a lawyer as a defender of a person subject to criminal prosecution are foreseen. The analysis of the criminal procedural legislation of the countries such as the Russian Federation, the Republic of Belarus, the Republic of Latvia, the Republic of Kazakhstan and the Republic of Uzbekistan demonstrates that the said criminal procedure codes, as well as the CPC of Ukraine, do not provide guarantees of protection in the form of compulsory involvement of a lawyer in criminal proceeding to a person with nonsufficient level of education. In addition, the legislator in most countries does not provide for the possibility of broad interpretation of the relevant rules, including the involvement of a lawyer in a mandatory manner. In particular, the analysis of criminal procedural legislation of countries such as the Russian Federation, the Republic of Belarus, the Republic of Kazakhstan and the Republic of Uzbekistan shows that list of cases for compulsory involvement of a lawyer are exhaustive [4-8].

Instead, according to paragraph 5 of clause 1 of Article 83 of Latvian Code of Criminal Procedure, "participation of a defence counsel in criminal proceedings is mandatory if the right to protection has an uneducated person or a person with such a low level of education that he cannot fully exercise their rights" [6]. We consider the relevant provision of the criminal procedural law to be progressive and justified.

At the same time, in our opinion, the relevant wording of the norms of Latvian criminal procedural law reveals the problem of insufficiency of clear criterion for determining minimal allowable level of education, below which involvement of the lawyer for such person is mandatory.

In our opinion, taking into account the constitutional requirements in many countries of the world, the obligation of the state to ensure the right to education of a certain level, the lack of an appropriate level of education guaranteed by the state is just that criterion for ensuring the right of a person to be protected in criminal procedure (in terms of right to defence).

In Ukraine, as already noted, it is provided at the constitutional level that full secondary education is compulsory. Therefore, we assume that absence of full secondary education is the reason for the mandatory involvement of a lawyer for person prosecuted. In cases of the lack of costs for the person concerned the said legal assistance should be provided free of charge.

\section{Conclusions}

The relevance of the study is justified not only by the lack of a unified approach in the practice of law enforcement regarding the application of legal grounds for the mandatory provision of a lawyer in criminal proceedings for persons who do not have the appropriate level of education (which necessitates changes to the national legislation), but also by the lack of a strictly defined level of education that would be considered sufficient to exercise persons' right to defence.

This necessitates the adjustment of national legislation by supplementing the relevant provisions of the procedural law of the following content: "obligatory participation of a lawyer is ensured in criminal proceedings against persons who do not have a level of education, which is determined by the legislation as compulsory." The relevant provision, in our opinion, will certainly be a positive factor in ensuring the observance of human rights in criminal prosecution. We believe that the relevant norm should also be introduced into the legislation of other countries with a similar to Ukrainian legal system. 


\section{References}

[1] Constitution of Ukraine, 1996, available at: https://zakon.rada.gov.ua/ cgibin/laws/main.cgi?nreg=254\%EA\%2F96\%2D\%E2\%F0

[2] Criminal Procedure Code of Ukraine, 2012, available at: https://zakon. rada.gov.ua/laws/show/4651-17

[3] The International Covenant on Civil and Political Rights, 1973, available at: https://www.ohchr.org/en/professionalinterest/pages/ccpr.aspx

[4] Criminal procedure code of Russian Federation, 2001, available at: http://pravo.gov.ru/proxy/ips/?docbody=\&nd=102073942

[5] Criminal procedure code of the Republic of Belarus, 1999, available at: http://kodeksy.by/ugolovno-processualnyy-kodeks

[6] Criminal procedure law of the Republic of Latvia, 2005, available at: https:// vvc.gov.lv/image/catalog/dokumenti/Criminal_Procedure_Law.pdf

[7] Criminal procedure code of the Republic of Kazakhstan, 2014, available at: http://kgd.gov.kz/ru/content/ugolovno-processualnyy-kodeks-rk

[8] Criminal procedure code of the Republic of Uzbekistan, 1994, available at: http://www.lex.uz/docs/111463

[9] The Law of Ukraine on Education, 2017, available at: https://zakon. rada.gov.ua/laws/show/2145-19/print

[10] The Constitution of the Republic of Kazakhstan, 1995, available at: http://mfa. gov.kz/en/hague/content-view/the-constitution-of-the-republic-ofkazakhstan

[11] Constitution of the Russian Federation, 1993, available at: http://www .mid.ru/en/ foreign_policy/official_documents/-/asset_publisher/CptICkB6BZ29/ content/id/571508

[12] Constitution of Latvia, 1993, available at: https://www.president.1v/ru/ latviiskaya-respublika/konstituciya-latvii

[13] Constitution of the Republic of Poland, 1997, available at: http://www.sejm. gov.pl/prawo/konst/angielski/kon1.htm

[14] Global Rise of Education, available at: https://ourworldindata.org/ global-rise-of-education 